\title{
EVALUASI KEBUTUHAN PENGGUNA JASA KONSTRUKSI DENGAN PENDEKATAN BUILDING INFORMATION MODELING
}

\author{
Mario Andrew ${ }^{1}$ dan Basuki Anondho ${ }^{2}$ \\ ${ }^{1}$ Program Studi Sarjana Teknik Sipil, Universitas Tarumanagara, Jl. Letjen S. Parman No.1 Jakarta \\ Email: mario.andrew@hotmail.com \\ ${ }^{2}$ Program Studi Sarjana Teknik Sipil, Universitas Tarumanagara, Jl. Letjen S. Parman No.1 Jakarta \\ Email: basukia@ft.untar.ac.id
}

\begin{abstract}
ABSTRAK
Dalam industri konstruksi, pengguna jasa konstruksi membutuhkan informasi yang baik atas prasyarat kebutuhannya. Di lain sisi, terdapat pengembangan model pengambilan keputusan melalui pendekatan Building Information Modeling yang merupakan alat bantu pengambilan keputusan untuk memudahkan kapabilitas dari suatu produk untuk berinteraksi yang dibutuhkan dalam proses perancangan dan pelaksanaan antara para pemangku kepentigan. Dalam penelitian ini, Building Information Modeling bertujuan untuk membantu pengguna jasa konstruksi mendapatkan jenis rumah tinggal yang sesuai dengan kebutuhannya. Identifikasi kebutuhan-kebutuhan rumah tinggal diberlakukan berbasis Value Engineering mendapatkan variabel kebutuhan dari fungsi rumah tinggal yaitu: faktor perlindugan, faktor keamanan, faktor kenyamanan, faktor aksesibilitas, faktor ekonomis, faktor kesehatan, faktor konservasi energi, dan faktor privasi. Kebutuhan-kebutuhan tersebut dimasukan ke dalam kuisioner dan didistribusikan kepada orang yang mempunyai rumah tinggal. Selanjutnya hasil dari kuisioner tersebut diolah dengan metode Relative Importance Index untuk mendapatkan bobot dari nilai kepentingan masing-masing kebutuhan. Faktor keamanan mempunyai bobot tertinggi dengan nilai RII sebesar 0.9644 dan faktor konservasi energi mempunyai bobot terendah dengan nilai RII sebesar 0.7289. Bobot-bobot tersebut di input didalam Building Information Modeling untuk dijadikan matriks keputusan beserta jenis-jenis rumah tinggal. Pengguna jasa konstruksi dapat memberikan skor kedalam matriks keputusan sesuai dengan kebutuhan yang sudah didapatkan dari studi literatur untuk mendapatkan total nilai untuk menentukan jenis rumah tinggal. Hasil evaluasi dari Building Information Modeling yang memperoleh input bobot kebutuhan yang dijadikan parameter terukur dalam penelitian ini dan di input skor dari pengguna jasa konstruksi menghasilkan total nilai tertinggi yang menjadi output dari Building Information Modeling yang dijadikan pilihan terbaik.
\end{abstract}

Kata kunci: Building Information Modeling, Value Engineering, Rumah Tinggal, Relative Importance Index.

\section{PENDAHULUAN}

Perkembangan manajemen konstruksi di negara kita secara umum, dan khususnya tidak dapat lepas dari perkembangan industri jasa konstruksi. Sedangkan perkembangan industri jasa konstruksi berhubungan erat dengan pelaksanaan pembangunan yang saat ini sedang giat dilaksanakan. Dalam pelaksanaan konstruksi yang dijalankan adanya tahap awal proyek yaitu tahap perencanaan dan perancangan. Tahap ini dilaksanakan sebelum tahap pelaksanaan pembangunan fisik lalu tahap operational dan tahap pemeliharaan (Ervianto, 2005). Dalam tahap awal ini akan melibatkan pihak-pihak yang terkait dalam pelaksanaan proyek yaitu pihak pengguna jasa konstruksi (owner), pihak perencana (designer), dan pihak kontraktor.

Pengguna jasa konstruksi (owner) sebagai pemilik proyek tentu memiliki kebutuhan yang diharapkan tercermin dalam produk yang diterimanya. Dalam setiap produk melekat fungsi dari setiap bagiannya. Fungsi-fungsi dari setiap kebutuhan dapat diklasifikasikan dengan pendekatan Value Engineering sesuai dengan kebutuhan yang diberikan oleh pengguna jasa konstruksi.

Pengguna jasa konstruksi membutuhkan informasi yang baik atas prasyarat kebutuhannya, termasuk kelayakan biaya berdasarkan fungsi kebutuhannya tersebut. Di lain sisi, terdapat pengembangan model pengambilan keputusan melalui pendekatan Building Information Modeling yang merupakan alat bantu pengambilan keputusan untuk memudahkan kapabilitas dari suatu produk untuk berinteraksi (interperobilitas data) yang dibutuhkan dalam proses perancangan dan pelaksanaan antara para pemangku kepentingan.(Zhang dan Nora, 2017). 
Implementasi BIM pada Value Engineering yang dilakukan akan membantu pengguna jasa konstruksi dalam melaksanakan proyek yang dijalankan. Membantu dalam segi alternatif terbaik, prioritas pekerjaan dan meminimalisir biaya kontrak yang ada. Untuk penelitian ini, dirancang Building Information Modeling berbasis Value Engineering untuk rumah tinggal. Hasilnya berupa parameter terukur atas alternatif desain sesuai kebutuhan pemilik proyek.

\section{Pengguna jasa}

Pemilik proyek (owner) adalah seseorang atau instansi tertentu yang memiliki hak terhadap suatu proyek yang dibangun dan membiayai seluruh pekerjaan dalam proyek tersebut. Dengan kata lain pemilik proyek (owner) merupakan orang atau badan yang memiliki proyek dan memberikan pekerjaan kepada penyedia jasa serta membayar biaya pekerjaan tersebut. Pemilik proyek (owner) juga akan menujuk suatu badan hukum pada jasa konstruksi sebagai konsultan perencana dan pemborong kerja atau kontraktor. (Gambatase, 2012).

\section{Rumah tinggal}

Dalam pengertian yang luas, rumah bukan hanya sebuah bangunan (struktural), melainkan juga tempat kediaman yang memenuhi syarat-syarat kehidupan yang layak, dipandang dari berbagai segi kehidupan masyarakat. Rumah dapat dimengerti sebagai tempat perlindungan, untuk menikmati kehidupan, dan beristirahat bersama keluarga. Di dalam rumah, penghuni memperoleh kesan pertama dari kehidupannya di dalam dunia ini. Rumah harus menjamin kepentingan keluarga, yaitu untuk tumbuh, memberi kemungkinan untuk hidup bergaul dengan tetangganya, dan lebih dari itu, rumah harus memberi ketenangan, kesenangan, kebahagiaan, dan kenyamanan pada segala peristiwa hidupnya.

\section{Value engineering}

Kajian dalam Value Engineering akan menggunakan pendekatan fungsional dan pendeketan sitem tersebut untuk analisisnya.Sepanjang tahap analisis, fungsi akan selalu menjadi dasar analis. Fungsi dalam desain bangunan gedung, jalan jembatan, pengairan dan fasilitas lainnya, dapat ditelursur pada TOR (Terms of Reference) atau rujukan kebutuhan yang ada, yang menjadi pedomain desainer dalam melakukan pekerjaan desain.Kemudian Value Engineering akan melakukan analisis “Apakah fungsi yang ditetapkan telah optimal ?” dijabarkan dalam komponenkomponen desain atau rancangan selanjutnya.

\section{FAST diagram}

FAST Diagram merupakan alat yang sangat kuat dalam menganalisis sistem yang kompleks, dan memaparkan deskripsi fungsi yang dilakukan ke dalam esensi tugas yang harus disampaikan (Borza, 2011). Persyaratan yang fungsinya dijelaskan dalam dua kata kata kerja - format kata benda yang saling berkaitan:

a. mempromosikan pemikiran kreatif dengan cara alternatif untuk memberikan fungsi;

b. membatasi perspektif untuk hanya melihat fungsi-fungsi berbingkai positif.

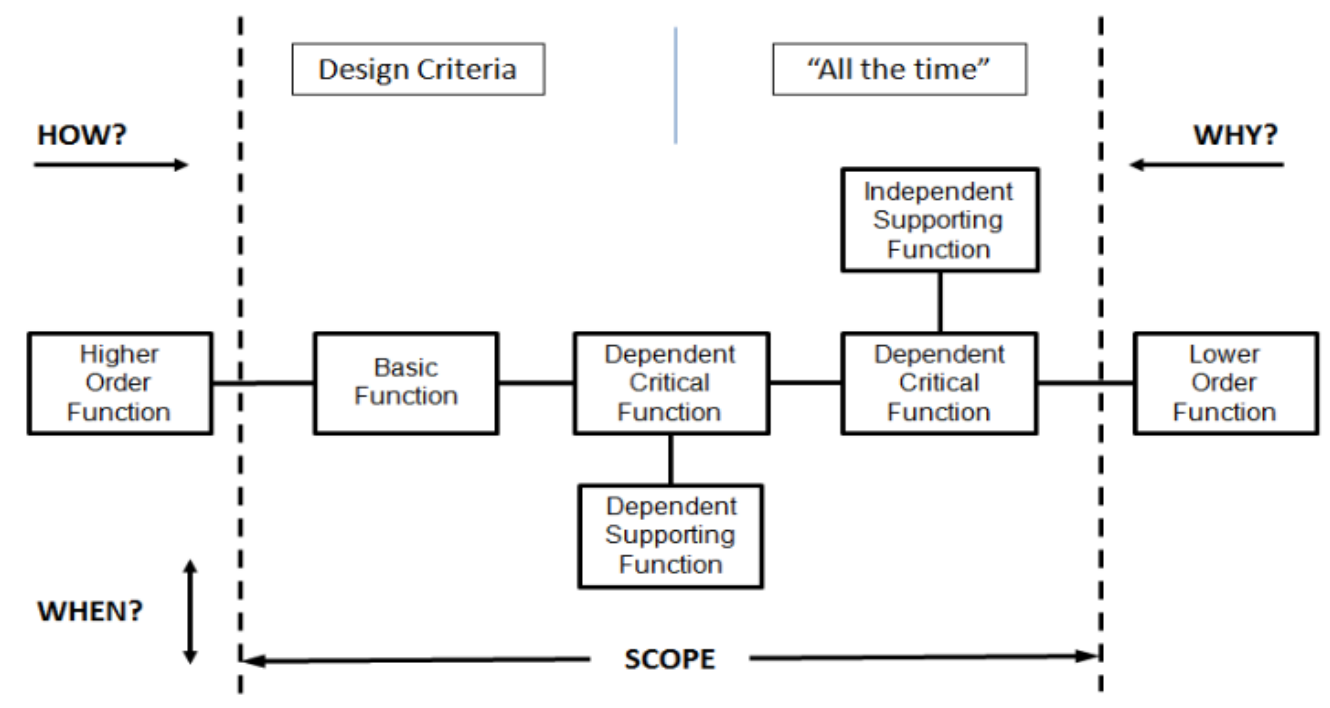

Gambar 1. FAST Diagram 
Higher Order Function merupakan fungsi yang paling penting dalam tinjauan tugas yang dibutuhkan dalam FAST Diagram. Dilanjutkan dengan Basic Function yang merupakan dasar dari fungsi-fungsi yang lain. FAST Diagram menjelaskan bagaimana dari Critical Path yang merupakan garis dari kanan ke kiri dan menjelaskan mengapa dari kiri ke kanan.

\section{Relative Importance Index(RII)}

Relative Importance Index (RII) digunakan untuk menentukan kepentingan relatif dari berbagai variabel yang dicari.(Rajgor et al, 2016). Skala lima poin berkisar dari 1 hingga 5 (skala yang sangat mempengaruhi) diadopsi dan diubah menjadi indeks kepentingan relatif (RII) untuk masing -masing faktor sebagai berikut:

$$
\text { RIIx }=\frac{\sum w}{(N x A)}
$$

$\mathrm{W}$ adalah pembobotan yang diberikan untuk setiap faktor oleh responden, A adalah bobot tertinggi ,dan $\mathrm{N}$ adalah jumlah total dari responden. Semakin tinggi nilai RII, yang lebih penting adalah fungsi terpenting.

RII digunakan untuk memberi peringkat penyebab yang berbeda. Peringkat ini memungkinkan untuk membandingkan secara silang kepentingan relatif dari faktor-faktor yang dirasakan oleh responden-responden. Setiap RII penyebab individu yang dirasakan oleh semua responden harus digunakan untuk menilai peringkat umum dan keseluruhan.

\section{Building Information Modeling (BIM)}

Menurut National Institute of Building Science, BIM adalah representasi digital dari fisik dan karakter fungsional dari suatu fasilitas. Sama seperti pembagian sumber pengetahuan untuk informasi tentang suatu fasilitas yang membuat basis yang diandalkan untuk keputusan selama siklus kehidupan awal dan seterusnya.

\section{Building Information Modeling sebagai teknologi}

Sebuah model informasi bangunan membawa semua informasi yang berkaitan dengan bangunan, termasuk karakteristik fisik dan fungsionalnya dan informasi siklus hidup proyek, dalam serangkaian "objek pintar". Misalnya, unit pendingin udara dalam BIM juga akan berisi data tentang prosedur pemasok, operasi dan pemeliharaan, laju alir, dan kebutuhan izin (Azhar dan Richter, 2009; Inovasi Konstruksi CRC, 2007) .

Eastman et al. (2011) mengindikasikan bahwa jenis-jenis model digital berikut tidak termasuk dalam kategori BIM: (1) model yang hanya berisi data 3D dan tidak ada atribut objek (yaitu hilang "i" dari BIM); (2) model tanpa dukungan perilaku; (3) model yang terdiri dari beberapa file referensi CAD 2D yang harus dikombinasikan untuk menentukan bangunan; dan (4) model yang memungkinkan perubahan dimensi dalam satu tampilan yang tidak secara otomatis tercermin dalam tampilan lain.

\section{Building Information Modeling sebagai proses}

BIM dapat dilihat sebagai proses virtual yang mencakup semua aspek, disiplin, dan sistem fasilitas dalam satu model virtual, yang memungkinkan semua anggota tim (pemilik, arsitek, insinyur, kontraktor, subkontraktor, dan pemasok) untuk berkolaborasi dengan lebih akurat dan efisien dari proses tradisional. Ketika model sedang dibuat, anggota tim terus-menerus menyempurnakan dan menyesuaikan bagian mereka sesuai dengan spesifikasi proyek dan perubahan desain untuk memastikan model seakurat mungkin sebelum proyek rusak secara fisik (Carmona dan Irwin, 2007). Fondasi BIM diletakkan pada dua pilar, komunikasi dan kolaborasi. Keberhasilan penerapan BIM membutuhkan keterlibatan awal dari semua pemangku kepentingan proyek. Ini berarti bahwa sistem pengiriman proyek tradisional (misalnya desain-tawaran-membangun) memiliki peran yang sangat terbatas dalam proyekproyek berbasis BIM.

\section{METODE PENELITIAN}

\section{Identifikasi kebutuhan pengguna jasa konstruksi}

Dalam penelitian ini, kebutuhan pengguna jasa konstruksi yang ditujukan untuk menentukan jenis pembangunan proyek rumah tinggal. Untuk mendapatkan kebutuhan-kebutuhan pengguna jasa konstruksi dibutuhkan studi literatur. Studi literatur merupakan tahap orientasi dari Value Engineering untuk mempersiapkan komponenkomponen yang berkait dengan kebutuhan pengguna jasa konstruksi. Untuk mengetahui komponen tersebut dibutuhkan studi literatur dengan menganalisis setiap komponen yang didapatkan dari berbagai jurnal dan buku. Komponen-komponen tersebut merupakan faktor fungsi rumah tinggal dari rumah tinggal. Setelah mendapatkan faktor-faktor tersebut, dikelompokan menjadi variable kebutuhan rumah tinggal. . 


\section{Membuat dan mendistribusi kuisioner}

Membuat dan mendistribusi kuisioner adalah tahap informasi dalam Value Engineering. Penyusunan kuisioner dilakukan setelah didapatkan faktor-faktor fungsi rumah tinggal. Faktor-faktor kebutuhan tersebut merupakan bahan-bahan untuk penyusunan kuisioner ini. Kuisioner ini dibuat dengan menggunakan skala likert. Skala likert merupakan skala yang dapat dipergunakan untuk mengukur sikap, pendapat, dan persepsi seseorang atau sekelompok orang tentang suatu gejala atau fenomena pendidikan (Djaali: 2008). Dengan kata lain, skala likert digunakan untuk mengukur atau menilai pilihan yang berjenjang. Variabel yang diukur dalam skala likert dijabarkan menjadi indikator variabel. Lalu indikator variabel tersebut digunakan untuk menjadi dasar atau titik tolak untuk menyusun instrumen berupa pernyataan dalam kuisioner ini.

Skala likert yang dipakai pada penelitian ini adalah:

1. Sangat tidak penting.

2. Tidak penting.

3. Cukup penting.

4. Penting.

5. Sangat penting.

Setelah hasil dari data kuisioner terkumpul dilakukan pengelompokan data. pengelompokan data pada penelitian ini mengklasifikasikan total nilai yang diberikan oleh skala likert pada setiap faktor-faktor yang tertera pada kuisioner.

\section{Perhitungan nilai kepentingan dengan metode relative importance index}

Penilaian melalui metode Relative Importance Index mendapatkan angka indikator kepentingan dari setiap fungsifungsi yang didapatkan dari hasil kuisioner. Indikator angka kepentingan ini menjadi bobot dan peringkat yang digunakan untuk pengambilan keputusan dalam Value Engineering. Rentang nilai RII yang dihasilkan adalah antara 0 dan 1.

\section{Pembuatan FAST diagram}

Hasil dari Relative Importance Index membantu untuk membuat FAST Diagram. Nilai kepentingan dari Relative Importance Index membuat peringkat yang menghasilkan Higher Order Function sebagai peringkat pertama sampai fungsi terakhir dari bagaimana sampai mengapa. Faktor fungsi rumah tinggal diurutkan sesuai dengan nilai kepentingan dari peringkat yang didapatkan dari kanan sampai kiri.

\section{Perancangan tabulasi dengan matriks keputusan}

Dalam tahap ini, hasil dari tahap fungsi yang berupa bobot-bobot nilai setiap komponen fungsi yang sudah didapatkan dimasukan dalam matriks keputusan (Decision Matrix). Format matriks tersebut menyatukan hasil dari bobot-bobot nilai setiap komponen dengan kebutuhan pengguna jasa konstruksi yang bertujuan untuk membangun rumah tinggal. Matriks keputusan ini membantu menentukan jenis rumah tinggal yang menjadi Opsi dalam pemodelan pada tabel 1 .

Tabel 1. Tabel Decision Matrix

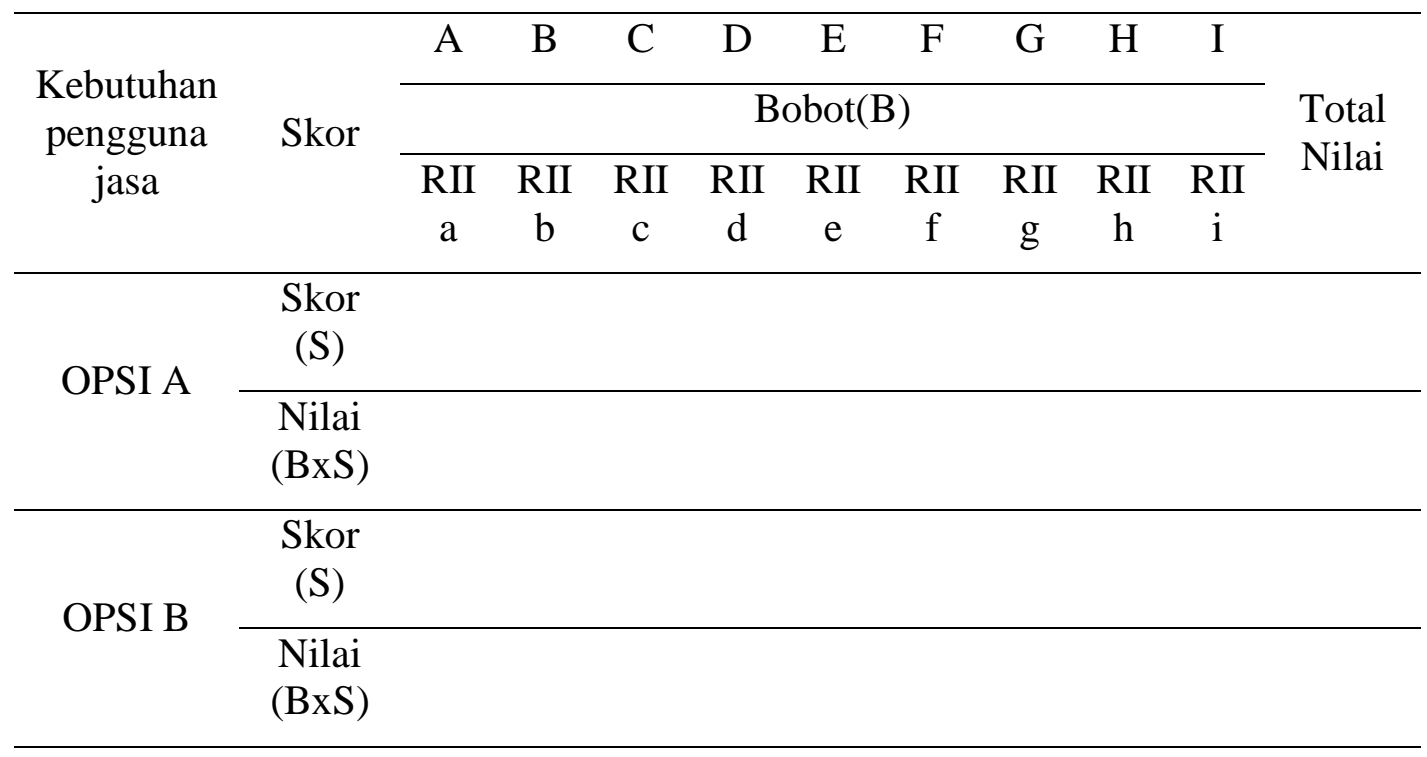


Kode A,B,C,D,E,F,G,H, dan I adalah komponen-komponen fungsi yang sudah didapatkan melalui studi literature. OPSI A dan OPSI B adalah jenis-jenis rumah tinggal yang didapatkan dari studi literatur untuk menentukan kebutuhan pengguna jasa yang dibutuhkan.Bobot(B) adalah RIIx yang merupakan hasil dari metode Relative Importance Index(RII) pada setiap variabel yang didapatkan dari studi literatur. Skor adalah skoring yang diberikan setiap opsi yang sudah didapatkan. Bobot(B) dan Skor(S) dikalikan untuk mendapatkan nilai setiap kebutuhan relatif dengan opsi yang ada. Nilai-nilai yang didapatkan dijumlahkan untuk mendapatkan total nilai pada kolom kanan dan menjadi perbandingan solusi setiap opsi.

\section{Analisis parameter terukur dengan decision matrix}

Hasil evaluasi dari Value Engineering yang sudah dibuat akan mendapatkan bobot-bobot kepentingan komponen fungsi yang didapatkan dari studi literatur sesuai dengan pengguna jasa konstruksi rumah tinggal. Building Information Modeling mengumpulkan data-data dari setiap komponen dari hasil kuisioner yang membuat bobot pada setiap komponen tersebut. Building Information Modeling yang dibuat adalah sebuah proses yang menyesuaikan kebutuhan pengguna jasa konstruksi dengan bobot-bobot yang sudah didapatkan menjadi parameter terukur dalam penelitian ini. Total nilai yang dikeluarkan menjadi pilihan terbaik dalam decision matrix untuk menentukan opsi pengguna jasa konstruksi rumah tinggal menyesuaikan dengan keperluan-nya.

Bobot yang didapatkan dari metode Relative Importance Index menyesuaikan dengan pemodelan Decision Matrix dalam Building Information Modeling. Setiap opsi yang didapatkan diklasifikasikan dari yang paling rendah sampai paling tinggi. Opsi-opsi tersebut diberi penilaian dengan skala yang semakin tinggi dari opsi yang paling rendah sampai opsi yang paling tinggi. Parameter terukur didapatkan dari total nilai masing-masing opsi untuk mendapatkan interval penentuan keputusan dalam Decision Matrix yang sudah dibuat.

\section{Pembuatan proses Building Information Modeling}

Hasil dari penelitian ini merupakan proses Building Information Modeling yang digunakan untuk membantu pengguna jasa konstruksi memutuskan opsi terbaik untuk digunakan dalam Value Engineering. Building Information Modeling yang dibuat mengumpulkan informasi-informasi yang dibutuhkan untuk bagian Value Engineering dengan sebuah model. Model ini menjadi patokan dengan informasi-informasi tersebut yang telah diteliti menjadi parameter terukur. Selanjutnya, Building Information Modeling bekerja dalam proyek untuk bekolaborasi dengan anggota tim lain untuk menyempurnakan persiapan proyek.(Azhar, 2012).

Pembuatan format input matriks keputusan dalam Microsoft excel sebagai tekonologi yang dipakai dalam Building Information Modeling penelitian ini. Format input tersebut dilampirkan dengan setiap kebutuhan untuk pengguna jasa memasukan skoring terhadap kebutuhan-kebutuhan yang didapatkan.

Skoring yang diberikan oleh pengguna jasa konstruksi menyesuaikan dengan kebutuhan pengguna jasa konstruksi untuk dimasukan kedalam model Building Information Modeling untuk dihitungkan total nilai-nya. Dengan matriks keputusan yang sudah dibuat dengan parameter terukur dari nilai Relative Importance Index. Total nilai tersebut menjadi penentuan jenis rumah tinggal yang pengguna jasa konstruksi butuhkan dan direkomendasikan kepada pengguna jasa konstruksi.

\section{HASIL DAN PEMBAHASAN}

\section{Identifikasi kebutuhan pengguna jasa konstruksi}

Hasil studi literatur penelitian terdahulu dipilih variabel yang muncul lebih dari satu pada penelitian terdahulu. Hasil identifikasi faktor fungsi rumah tinggal tersebut yang akan digunakan dalam penelitian ini dan penjelasan nya, dapat dilihat pada tabel 2 . 
Tabel 2. Variabel kebutuhan rumah tinggal

\begin{tabular}{|c|c|c|}
\hline No & Variabel & Keterangan \\
\hline 1 & Perlindungan & $\begin{array}{l}\text { Menjadi tempat untuk berlindung dari gangguan-gangguan } \\
\text { iklimuntuk penghuni rumah tinggal. }\end{array}$ \\
\hline 2 & Kenyamanan & $\begin{array}{c}\text { Meningkatkan kenyamanan kepada penghuni rumah tinggal } \\
\text { untuk melakukan kegiatan sehari-hari. }\end{array}$ \\
\hline 3 & Keamanan & $\begin{array}{c}\text { Memberikan keamanan mencegah pencurian dan } \\
\text { kebakaran. }\end{array}$ \\
\hline 4 & Aksesibilitas & $\begin{array}{l}\text { Mempunyai akses yang mudah untuk penghuni rumah } \\
\text { dalam kegiatan sehari-hari diluar rumah. }\end{array}$ \\
\hline 5 & Kesehatan & Menfasilitasi tingkat kesehatan penghuni rumah tinggal. \\
\hline 6 & Ekonomis & Menyesuaikan dengan pendapatan penghuni rumah tinggal. \\
\hline 7 & Konservasi Energi & Memiliki konsep rumah tinggal hemat energi. \\
\hline 8 & Desain Rumah & $\begin{array}{l}\text { Memberikan kepuasan terhadap pemilik rumah tinggal } \\
\text { dengan estetika dan bentuk dari rumah tinggal tersebut. }\end{array}$ \\
\hline 9 & Privasi & Meningkatkan privasi individu penghuni rumah tinggal. \\
\hline
\end{tabular}

\section{Distribusi dan pengumpulan data}

Kuisioner yang telah dihasilkan kemudian didistribusikan ke beberapa pemilik rumah dan/atau pengguna jasa konstruksi rumah. Responden dari kuisioner ini merupakan pemilik rumah tinggal dan/atau pengguna jasa konstruksi rumah tinggal yang sudah beberapa tahun dengan sejumlah anggota keluarga.

\section{Analisis dengan Relative Importance Index}

Setelah dilakukan pengumpulan data kuisioner, setiap variabel dihitung menggunakan metode Relative Importance Index (RII). Berikut menggunakan rumus RII:

$$
\mathrm{RII}=\frac{\sum w}{(N x A)}
$$

- $\mathrm{RII}=$ Relative Importance Index

- $\mathrm{W} \quad=$ Nilai yang diberikan oleh setiap responden

- $\mathrm{N} \quad=$ Jumlah Responden

- $\mathrm{A}=$ Penilaian tertinggi dalam skala likert (5)

Contoh perhitungan Relative Importance Index :

Faktor Perlindungan :

$\sum w=$ Jumlah nilai yang diberikan oleh setiap responden $=214$

$$
\begin{aligned}
N & =\quad \text { Jumlah responden } & & =45 \\
A & =\text { Penilaian tertinggi dalam skala likert }(5) & & =5 \\
\mathrm{RII} & =\frac{\sum w}{(N x A)}=\frac{214}{(45 \times 5)} & & =0.9511
\end{aligned}
$$

Hasil dari metode Relative Importance Index (RII) menghasilkan bobot dan peringkat dari setiap variabel yang digunakan : 


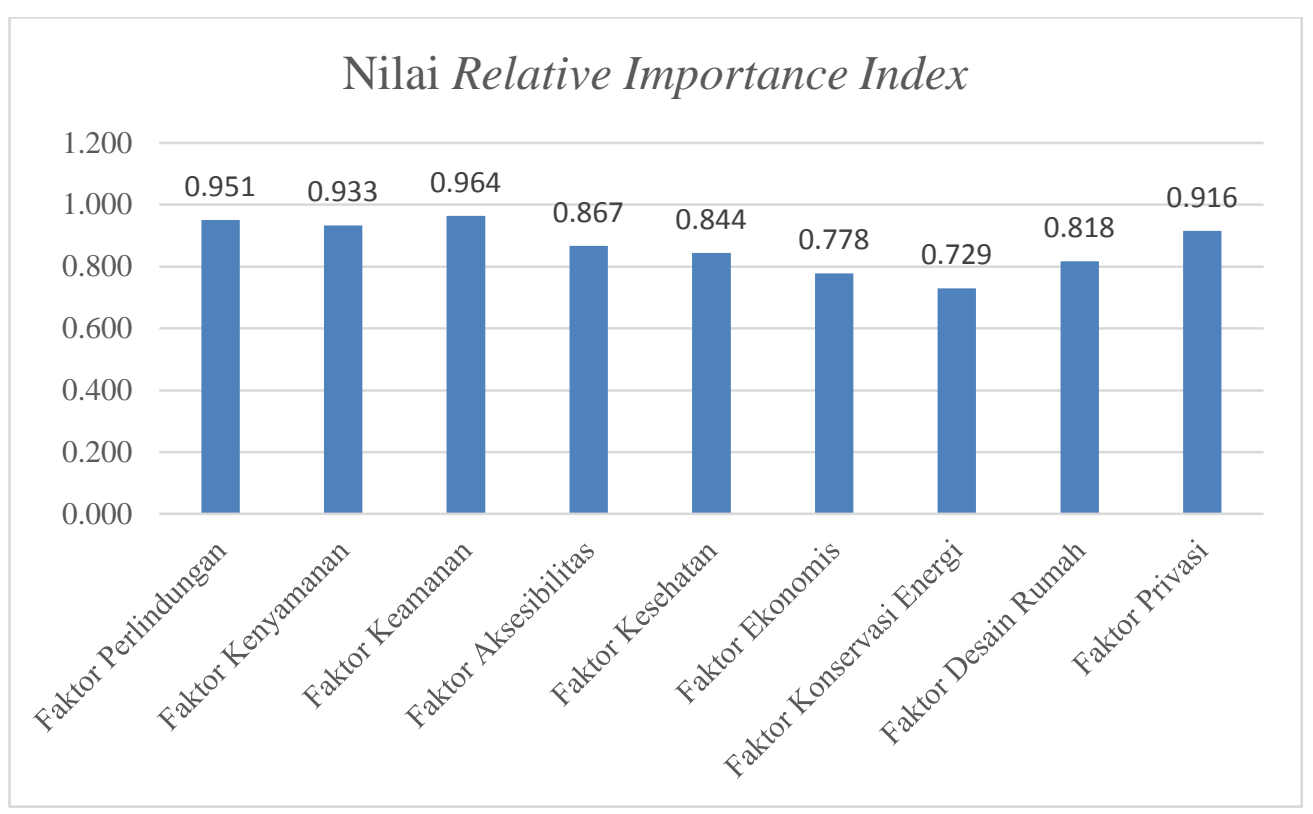

Gambar 2. Grafik Nilai Relative Importance Index

Tabel 3. Hasil Relative Importance Index

\begin{tabular}{llc}
\hline \multicolumn{1}{c}{ Variabel } & RII & PERINGKAT \\
\hline Faktor Keamanan & 0.9644 & 1 \\
\hline Faktor Perlindungan & 0.9511 & 2 \\
\hline Faktor Kenyamanan & 0.9333 & 3 \\
\hline Faktor Privasi & 0.9155 & 4 \\
\hline Faktor Aksesiblitas & 0.8667 & 5 \\
\hline Faktor Kesehatan & 0.8444 & 6 \\
\hline Faktor Desain Rumah & 0.8177 & 7 \\
\hline Faktor Ekonomis & 0.7777 & 8 \\
\hline Faktor Konservasi Energi & 0.7289 & 9 \\
\hline
\end{tabular}

Dari hasil Relative Importance Index diatas menunjukkan Faktor Keamanan adalah fungsi rumah tinggal yang paling penting dengan mempunyai nilai RII sebesar 0.9644 dan Faktor Konservasi Energi adalah fungsi rumah tinggal yang paling tidak penting dengan mempunyai nilai RII sebesar 0.7289 .

\section{Analisis FAST diagram}

Dari angka kepentingan yang didapatkan, dijadikan peringkat untuk menyesuaikan FAST Diagram yang dibuat. Dengan Faktor Keamanan yang merupakan peringkat pertama dijadikan Basic Function. Setelah itu, fungsi-fungsi berikutnya yang sudah didapatkan dalam hasil RII diurutkan dalam Critical path.

FAST Diagram menjelaskan interaksi dari setiap fungsi yang ada dari Higher Order Function yang merupakan fungsi tujuan dari FAST Diagram tersebut dan Lower Order Function yang merupakan fungsi hasil dari FAST Diagram. Dalam penelitian ini, Higher Order Function dari rumah tinggal adalah menjadi Hunian yang baik bagi para penghuni-nya. FAST Diagram ini menjelaskan "Bagaimana rumah tinggal menjadi hunian yang baik ?" dari kanan sampai kiri.

Lower Order Function yang merupakan fungsi hasil dari FAST Diagram adalah Area yang dihuni oleh penghuninya. FAST Diagram menjelaskan "Mengapa rumah tinggal memerlukan area yang dihuni ?" dari kiri sampai kanan. 
Hal ini menyimpulkan bahwa FAST Diagram menghasilkan interaksi antara fungsi satu sama lain yang berurutan dari angka kepentingan yang didapat dari metode Relative Importance Index.

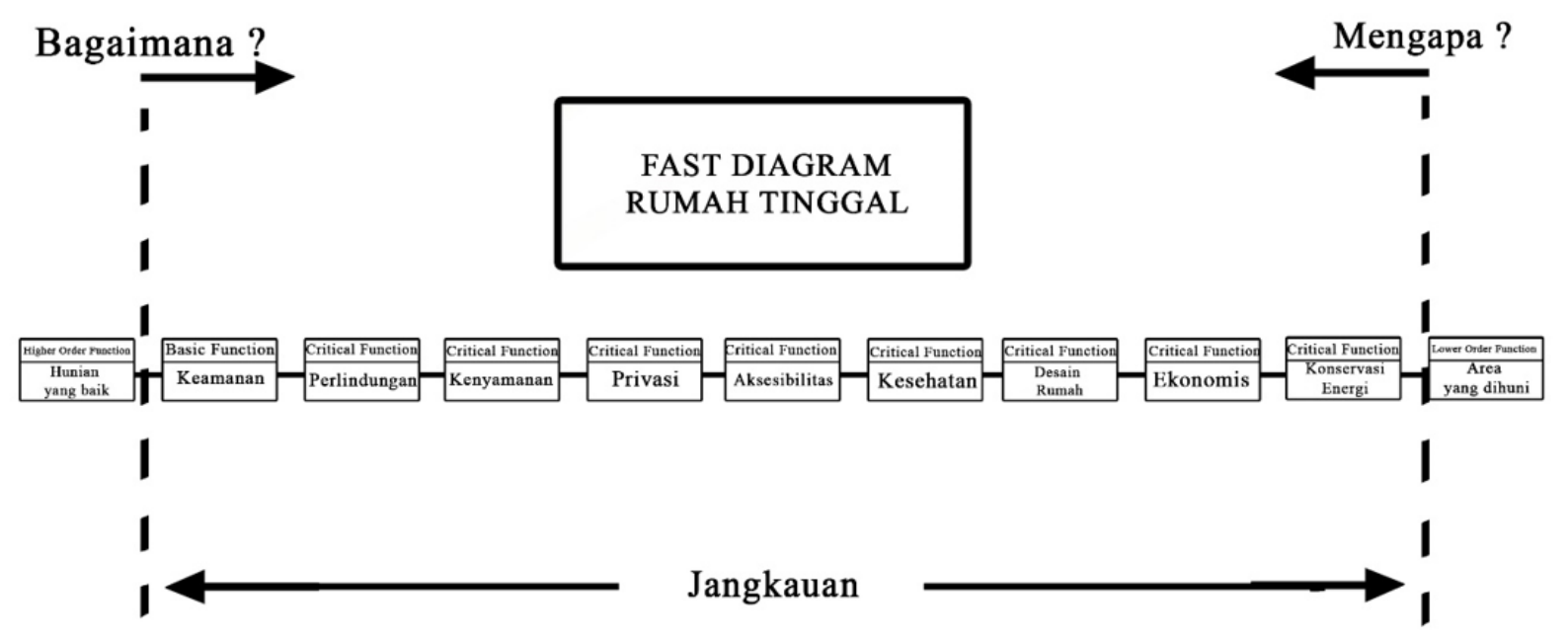

Gambar 3. Hasil FAST Diagram

FAST Diagram ini menjelaskan fungsi yang paling penting sampai yang paling tidak penting dan menggambarkan kesinambungan diantara fungsi-fungsi satu sama lain

\section{Pemodelan decision matrix dalam Building Information Modeling}

Hasil dari Relative Importance Index menghasilkan bobot yang dipakai dalam pembuatan Decision Matrix dalam Building Information Modeling. Decision Matrix dapat dilihat dalam tabel 4.

Tabel 4. Tabel Decision Matrix

\begin{tabular}{|c|c|c|c|c|c|c|c|c|c|c|c|}
\hline \multirow{3}{*}{$\begin{array}{c}\text { Kebutuhan } \\
\text { pengguna } \\
\text { jasa }\end{array}$} & \multirow[t]{3}{*}{ Skor } & $\begin{array}{c}\text { Faktor } \\
\text { Perlindungan }\end{array}$ & $\begin{array}{c}\text { Faktor } \\
\text { Kenyamanan }\end{array}$ & $\begin{array}{c}\text { Faktor } \\
\text { Keamanan }\end{array}$ & $\begin{array}{c}\text { Faktor } \\
\text { Aksesibilitas }\end{array}$ & $\begin{array}{c}\text { Faktor } \\
\text { Kesehatan }\end{array}$ & $\begin{array}{c}\text { Faktor } \\
\text { Ekonomis }\end{array}$ & $\begin{array}{c}\text { Faktor } \\
\text { Konservasi } \\
\text { Energi }\end{array}$ & $\begin{array}{l}\text { Faktor } \\
\text { Desain } \\
\text { Rumah }\end{array}$ & $\begin{array}{l}\text { Faktor } \\
\text { Privasi }\end{array}$ & \multirow{3}{*}{$\begin{array}{l}\text { Total } \\
\text { Nilai }\end{array}$} \\
\hline & & \multicolumn{9}{|c|}{ Bobot $(\mathrm{B})$} & \\
\hline & & 0.95 & 0.93 & 0.96 & 0.87 & 0.84 & 0.78 & 0.73 & 0.82 & 0.92 & \\
\hline \multirow{2}{*}{$\begin{array}{c}\text { Rumah } \\
\text { Sangat } \\
\text { Sederhana } \\
\text { (RSS) }\end{array}$} & Skor(S) & & & & & & & & & & \\
\hline & Nilai & & & & & & & & & & \\
\hline \multirow{2}{*}{$\begin{array}{c}\text { Rumah } \\
\text { Sederhana } \\
(\mathrm{RS})\end{array}$} & Skor(S) & & & & & & & & & & \\
\hline & Nilai & & & & & & & & & & \\
\hline \multirow{2}{*}{$\begin{array}{c}\text { Rumah } \\
\text { Kelas } \\
\text { Menengah }\end{array}$} & Skor(S) & & & & & & & & & & \\
\hline & Nilai & & & & & & & & & & \\
\hline \multirow{2}{*}{$\begin{array}{l}\text { Rumah } \\
\text { Kelas } \\
\text { Mewah }\end{array}$} & Skor(S) & & & & & & & & & & \\
\hline & Nilai & & & & & & & & & & \\
\hline
\end{tabular}

Dalam Decision Matrix ini menjelaskan dengan pengguna jasa konstruksi memberikan skor (S) setiap fungsi rumah tinggal sesuai dengan jenis-jenis rumah tinggal sesuai yang ditujukan pengguna jasa konstruksi tersebut. Namun, skor-skor tersebut dikalikan dengan bobot (B) yang sudah diteliti dalam penelitian ini. Skor-skor tersebut dikalikan dengan bobot (B) yang sudah diteliti dalam penelitian ini sebagai parameter terukur untuk mendapatkan total nilai (BxS) untuk jenis-jenis rumah tinggal yang diberikan. Total nilai diantara jenis-jenis rumah tinggal yang diberikan pengguna jasa konstruksi menjadi pilihan utama dalam perancangan rumah tinggal sesuai dengan kebutuhan pengguna jasa konstruksi.ingatkan total nilai $(\mathrm{BxS})$ untuk jenis-jenis rumah tinggal yang diberikan.

\section{Analisis parameter terukur}

Parameter terukur ini dikalkulasikan dalam Microsoft excel untuk menghasilkan penilaian sesuai dengan setiap jenis rumah tinggal. Untuk rumah tinggal sangat sederhana di input skor 1 pada setiap baris nya sampai rumah tinggal kelas mewah di input skor 4. Dengan ketentuan seperti ini menghasilkan seperti pada Tabel 5. 
Tabel 6. Hasil Parameter Terukur

\begin{tabular}{cc}
\hline PARAMETER TERUKUR & JENIS RUMAH TINGGAL \\
\hline $0-7.8001$ & Rumah Tinggal Sangat Sederhana \\
\hline $7.80011-15.6002$ & Rumah Tinggal Sederhana \\
\hline $15.60021-23.4003$ & Rumah Kelas Menengah \\
\hline $23.40031-31.2004$ & Rumah Kelas Mewah
\end{tabular}

Dengan parameter terukur yang sudah dibuat, dimasukan kedalam pemodelan Building Information Modeling untuk melanjutkan analisis terhadap kebutuhan pengguna jasa konstruksi.

\section{Input pada Building Information Modeling}

Pengguna jasa konstruksi menginput skor terhadap kebutuhan yang diinginkan. Skor-skor tersebut digunakan untuk dimasukan kedalam matriks keputusan yang telah dibuat. Skala dalam skoring yang dilakukan oleh pengguna jasa konstruksi dipakai skala likert 0-4 dari nilai 0 untuk sangat tidak penting sampai 5 untuk sangat penting. Model Input pada Building Information Modeling ini dilampirkan pada lampiran 3 dalam bentuk formulir kepada pengguna jasa konstruksi.

Hasil dari input pada Microsoft excel dimasukan kedalam Building Information Modeling. Hasil ini di input oleh peserta konstruksi yang mempunyai akses ke Building Information Modeling untuk mengukur total nilai yang terbanyak secara kumulatif.

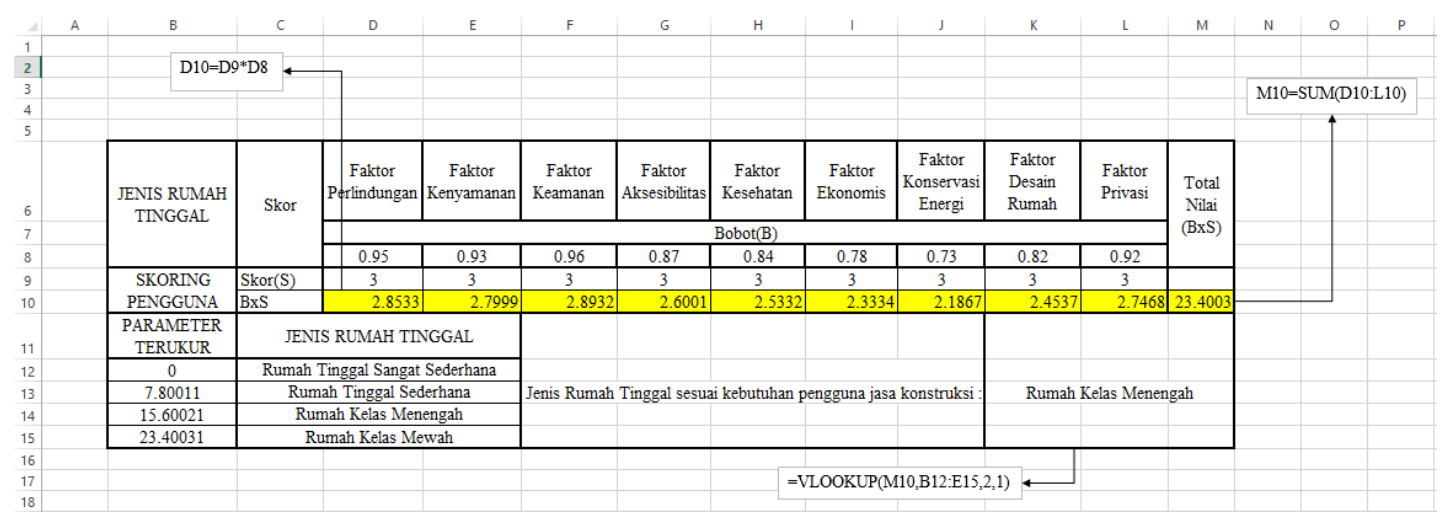

Gambar 4. Contoh input skor pada Building Information Modeling

Hasil Evaluasi dari kebutuhan pengguna jasa konstruksi didapatkan dari total nilai dari pemasukan skor yang dikalikan dengan bobot setiap kebutuhan pengguna jasa konstruksi. Dalam gambar 4.3 menjelaskan input skor yang dimasukan ke dalam Microsoft Excel untuk dikalkulasikan dengan bobot(B) seperti pada cell D10. Total nilai dari setiap kebutuhan rumah tinggal dikalkulasikan pada setiap baris tipe jenis rumah tinggal dengan rumus Microsoft Excel seperti pada cell M10. Total nilai merupakan output dari Building Information Modeling yang digunakan untuk penentuan keputusan jenis rumah tinggal yang pengguna jasa konstruksi butuhkan. Output dari Building Information Modeling yang merupakan total nilai dihasilkan dengan bentuk jenis rumah tinggal dengan formulasi kalkulasi seperti yang diterangkan di gambar 4.3.

\section{KESIMPULAN DAN SARAN}

\section{Kesimpulan}

Hasil dari Relative Importance Index memberi bobot masing-masing kebutuhan fungsi rumah tinggal degan Faktor Keamanan yang paling tinggi yaitu 0,9644 dan Faktor Konservasi Energi yang paling rendah yaitu 0,7289. Bobot ini didapatkan dari 45 responden yang mempunyai rumah tinggal dan tinggal di rumah tinggal sendiri. Faktor keamanan menjadi kebutuhan terpenting dibanding faktor-faktor kebutuhan lainnya. Hal ini membuktikan faktor keamanan sebagai Higher Order Function dalam interaksi pada FAST Diagram.

Building Information Modeling dalam penelitian ini bekerja sebagai proses dan teknologi. Proses yang membantu Value Engineering menentukan jenis rumah tinggal terbaik dan teknologi sebagai input dan output yang memberi total nilai terbaik untuk jenis rumah tinggal yang dipakai sesuai dengan kebutuhan-nya. Teknologi yang dipakai pada Building Information Modeling ini adalah Microsoft excel yang menjadi teknologi pengguna jasa memasukan 
nilai kedalam model matriks keputusan Building Information Modeling. Microsoft Excel menjadi wadah Building Information Modeling sebagai teknologi dengan formulasi membantu menampilkan hasil jenis rumah tinggal sesuai dengan kebutuhan pengguna jasa konstruksi.

Parameter terukur yang didapatkan dalam penelitian ini cukup membantu Value Engineering dalam menentukan jenis rumah tinggal yang sesuai dengan kebutuhan pengguna jasa konstruksi. Parameter terukur bekerja sebagai informasi hasil dari Value Engineering terhadap Building Information Modeling .

\section{Saran}

Berdasarkan penelitian dan analisis yang telah dilaksanakan, saran-saran untuk penelitian selanjutnya adalah :

1. Penambahan jumlah data untuk mendapatkan parameter terukur yang lebih baik dan akurat. Hasil dari simulasi analisis data yang telah dilakukan, ditemukan bahwa jumlah data berpengaruh terhadap hasil penelitian.

2. Memperbanyak faktor fungsi yang di indentifikasi melalui literatur. Dari studi literatur yang ditemukan mendapatkan faktor-faktor kebutuhan rumah tinggal dengan jumlah 13 jurnal. Dengan meneliti faktor-faktor kebutuhan lebih banyak jumlah jurnal-nya dapat mendapatkan faktor-faktor yang lebih banyak dan menambah informasi kedalam Building Information Modeling.

3. Dapat dilakukan penelitian lebih lanjut dengan melakukan uji validasi terhadap beberapa proyek pembangunan rumah tinggal untuk mendapatkan nilai-nilai yang dimasukan kedalam Building Information Modeling yang sudah didapatkan dalam penelitian ini.

\section{DAFTAR PUSTAKA}

Azhar, Salman.(2012). "Building Information Modeling (BIM): Now and Beyond". Australasian Journal of Construction Economics and Buildings, Vol 12 (2012):15-28.

Borza, John. (2011). FAST Diagrams: The Foundation for Creating Effective Function Models. General Dynamic Land Systems, Michigan, United States of America.

Carmona,J., and Irwin, K. (2007). "BIM: Who, what, how and why" . Building Operation Management, October 2007.

Djaali, (2008). Psikologi Pendidikan. Bumi Aksara, Jakarta, Indonesia.

Ervianto, W. (2005). Manajemen Proyek Konstruksi (Edisi Revisi). Penerbit Andi, Yogyakarta, Indonesia.

Gambatase, John. (2012). "Owner Involvement in Construction Site Safety”. Construction Congress, Vol 6.

Rajgor, Matama., Chauhan Paresh, and Patel Dhruv. (2016). "RII \& IMPI: Effective Techniques for Finding Delay in Construction Project”. ISO 9001:2008 Certified Journal.e-ISSN: 2395-0056.

Zhang and Nora. (2017). "BIM-Integrated Systems for Automated Value Analysis of Buildings". University of California. 